\title{
FUNGSI SIMBOLIK PERAYAAN ERAU DI TENGgARONG (KAJIAN SEMIOTIKA)
}

\section{SYMBOLIC FUNCTION IN CELEBRA TION ERAU TENGGARONG (SEMIOTICS STUDY)}

\author{
Ulum Janah \\ Fakultas Sastra, Universitas Balikpapan, Kalimantan Timur \\ ulum.jannah@uniba-bpn.ac.id
}

\begin{abstract}
Abstrak
Penelitian "Fungsi Simbolik Perayaan Erau di Tenggarong" merupakan penelitian lapangan. Objek penelitian ini adalah Perayaan Erau. Erau menunjukkan identitas masyarakat dan menunjukkan rasa persatuan di wilayah Kutai melalui fungsi simbolis perayaan tersebut. Untuk menganalisis prosesnya, penelitian ini menggunakan pendekatan semiotik milik Peirce. Hasilnya menunjukkan kegiatan dalam perayaan Erau di Tenggarong memiliki makna simbolis bagi masyarakat pemilik adat untuk mengkonfirmasi identitasnya. Selain itu, simbol juga berfungsi sebagai bentuk ekspresif, kreatif, psikologi, dan sosial bagi masyarakat adat maupun masyarakat umum di Tenggarong. Simbol tersebut menggambarkan orang pertama dan pemimpin di Kutai yang memiliki struktur berupa elemen-elemen yang saling terkait antara pemilik adat, dalam hal ini dari pihak kesultanan dan masyarakat sekitar.
\end{abstract}

Kata kunci: Erau, simbol, semiotik Peirce, fungsi

\section{Abstract}

The "Functions of Symbolic Celebration Erau in Tenggarong" is the result of a field research. The object of this study are Erau Celebration. The Erau shows communities identity and demonstrate a sense of Unity in Kutai region through the symbolic function of the celebration. To analyse the process, this paper used semiotic approach by Peirce. The results indicate that the activities in Erau Celebration in Tenggarong have a symbollic meaning for the people of indigenous owners to confirm his identity. In addition, the symbols also have functioned as expressive, creative, psychology, and social forms for indigenous peoples as well as general public in Tenggarong. The symbol draws the first person and the leader of Kutai and their interrelated structural element and interdependency between indigenous owners, in this case from the sultanate and the surrounding communities.

Keywords: Erau, symbols, semiotics Peirce, function

\section{Pendahuluan}

Perpaduan sastra dan kebudayaan memberikan warna tersendiri bagi perkembangan dunia sastra. Kebudayaan sebagai media perwujudan suatu karya sastra akhirnya dapat menjadi objek penelitian sastra. Hal tersebut dikarenakan rangkaian acara kebudayaan menunjukkan nilainilai simbolik tentang kehidupan bagi masyarakat pemilik adat dan masyarakat pendatang pada umumnya. Sementara itu, sastra sendiri tidak semata-mata dipahami sebagai imajinasi, melainkan sebagai gejala kultural yang ada juga membicarakan masalah masa lampau, seperti mitos, fable, legenda serta bentuk-bentuk kepercayaan lainnya (Ratna, 2011).

Cerita rakyat sebagai salah satu bentuk karya sastra yang diangkat dalam upacara adat tidak sekadar cerita biasa, melainkan pemilik adat itu memiliki keyakinan atas kesakralan yang terdapat dalam cerita tersebut sehingga mampu pula memberikan nilai-nilai luhur dalam upacara adat yang diadakan. Cerita rakyat dalam karya sastra merupakan bagian dari folklor dan upacara adat sebagai objek visual kebudayaan tidak terlepas dari kepercayaan yang dimiliki oleh masyarakat adatnya. Kepercayaan yang dimiliki secara turun-temurun tersebut dapat diperoleh melalui tindakan yang teratur dan dilakukan pada waktu-waktu tertentu setiap tahunnya serta dapat diperoleh dari mitologimitologi yang diyakininya.

Sehubungan dengan hal tersebut, penelitian ini bertitik tolak dari sebuah kisah tentang Putri Karang Melenu, Permaisuri Aji Batara Agung Dewa Sakti (sekaligus perempuan) yang menurunkan Sultan-sultan Kutai Kartanegara Ing Martadipura. Di balik cerita tersebut tersembunyi mitos yang sangat disakralkan oleh 
masyarakat khususnya di lingkungan Kesultanan Kutai, Kalimantan Timur. Tidak seperti puisi, mitos diterjemahkan tanpa kehilangan nilai, sedangkan puisi harus kehilangan beberapa signifikansi jika bunyi kata-kata di mana puisi diungkapkan. Mitos berhubungan dengan sejarah sakral, yaitu kejadian kuno yang terjadi pada permulaan waktu, ab initio. Pelaku-pelaku mitos bukanlah manusia, mereka adalah para dewa atau pahlawan. Selain itu, mitos merupakan sejarah mengenai apa yang terjadi in illo tempore, cerita mengenai apa yang dewa-dewa/ makhluk setengah dewa lakukan pada permulaan waktu (Badcock, 2008 dan Eliade, 2002). Lebih lanjut, ketertarikan peneliti akan mitos sakral yang terdapat dalam cerita Putri Karang Melenu membawa peneliti pada suatu ritual yang selalu dilakukan oleh Kesultanan Kutai Kartanegara. Ritual tersebut menjadi objek penelitian yang memiliki simbol-simbol bermakna. Melalui bantuan kisah Putri Karang Melenu, semiotika dalam ritual tersebut dapat dianalisis.

Ritual tersebut secara rutin diadakan setiap tahun pada saat Perayaan Erau. Pemangku Adat Sakral Kesultanan Kutai Kartanegara, Drs. Awang Imaluddin, menjelaskan bahwa ritual tersebut didasarkan pada Kisah Putri Karang Melenu. Kisah Putri Karang Melenu yang ternarasikan dalam karya sastra menjadi dasar ritual adat yaitu Beluluh Sultan lebih tepatnya berupa totem. Totem diambil dari bahasa Indian Amerika Utara ototeman berarti "kekerabatan", "saudaranya". Totem ini ada yang menjadi milik perorangan dan ada yang menjadi milik golongan, suku dan bangsa. Namun, di dalam terdapat kesamaan semacam kesatuan, partisipasi, saling menjadi bagian dari lainnya, sehingga menimbulkan kekuatan luar biasa (Hastings dalam Ismail, 1990). Sementara itu totem menurut Frazer sebagai berikut.

A class of material objects which a savage regard with superstitious respect, believing that there exists between him and every member of the class an intimate and altogether special relation. The connection between a man and his totem is mutually beneficent; the totem protects the man, and the man shows his respect for the totem in various ways, by not killing it if it be an animal, and not cutting or gathering it if it be a plant. As distinguished from a fetish, a totem is never an isolated individual, but always a class of objects, generally a species of animals or of plants, more rarely a class of inanimate natural objects, very rarely a class of artificial objects (Freud, 2001).

Totem dalam Kisah Putri Karang Melenu yaitu ular sawah (yang ditemukan oleh Petinggi Hulu Dusun) sampai tenggelamnya naga di Sungai Mahakam, sampai pada cerita kelahiran Putri Karang Melenu yaitu setelah tenggelamnya naga kemudian muncul bayi perempuan yang selanjutnya diberi nama Putri Karang Melenu. Dari sudut inilah signifikansi mengenai cerita Putri Karang Melenu dalam kontruksi pemikiran tentang kehidupan manusia, khususnya asal-usul anak keturunan Kesultanan Kutai menjadi dasar pada ritual Beluluh Sultan yang merupakan upacara pensucian atau pembersihan diri Sultan.

Dengan demikian, Prosesi Adat Beluluh Sultan lantas menjadi dan dijadikan media mengingat dan meneguhkan ide tentang asalusul "Raja" atau keturunan "Raja" bahwa mereka "bukan" manusia biasa. Mitologi ular sawah menjelma menjadi naga, kemudian ketika diturunkan ke Sungai Mahakam memunculkan seorang bayi perempuan yang diberi nama Putri Karang Melenu. Mitologi demikian, dewasa ini menjadi sangat penting dikaji karena dari sudut ini pula akan ditemukan benang merah bagaimana kearifan lokal (local wisdom) mengejawantah dan diejawantahkan lewat serangkaian upacara adat tersebut sampai sekarang.

\section{Semiotika Peirce}

Cara untuk menentukan makna dibalik tanda-tanda sebagaimana yang dielementasikan dalam ritual membutuhkan acuan teoritik. Peirce (1931) memandang tanda sebagai struktur yang cenderung "dimotivasi" oleh suatu bentuk simulasi. Ia menyebut tanda sebagai representamen (secara literal berarti "yang merepresentasikan), sedangkan konsep, benda, gagasan, dan lainnya yang diacu sebagai objek. Sementara itu, makna yang diperoleh dari sebuah tanda diberi istilah interpretan. Ketiga hal tersebut lazim digunakan dalam pelbagai karya semiotika saat ini, dengan menggunakan istilah yang umum yaitu, ikon, indeks, dan simbol. Ikonitas adalah upaya untuk mensimulasikan sifat inderawi yang dipersepsikan dalam pelbagai benda. Indeksikalitas berisi strategi yang mengacu pada eksistensi dan lokasi objek dalam ruang dan waktu. Berikutnya, simbolisme merupakan hasil dari kesepakatan historis dan sosial, persetujuan, atau fakta.. 
Charles Sanders Peirce (1931: CP1.372) menyatakan bahwa untuk mengkaji objek agar bisa dipahami, perlu dilihat dari tiga jalur logika secara padu, yaitu: (1) Hubungan penalaran dengan jenis penandanya, (2) Hubungan kenyataan dengan jenis dasarnya, dan (3) Hubungan pikiran dengan jenis penandanya (Peirce, 1931).

Mengapa ketiga jalur itu perlu dipadukan? Hal ini karena tanda, baik dalam wujud sebagai ikon, indeks, dan simbol, memiliki nuansa-nuansa yang dibedakan. Pada ikon didapatkan kesamaan yang tinggi antara yang diajukan sebagai penanda dan yang diterima oleh pembaca sebagai hasil petandanya. Bentuk-bentuk diagram, lukisan, gambar sketsa, patung, kaligrafi, ukir-ukiran, dan yang tampak sebagai tata wajah (grafika atau tipografi dalam bentuk-bentuk ikonis) merupakan contoh bagi tanda-tanda yang bersifat ikonis.

Jika ditelusuri lebih lanjut, tanda-tanda yang bersifat ikonis ini, menjelaskan adanya relasi-relasi yang argumentatif (sebab-akibat) sehingga tanda-tanda tadi menjadi indeks. Memahami indeks berarti memahami signifikansinya. Di sinilah tanda-tanda yang digunakan teratur dalam upacara (ritme) tadi menjadi kata sifat simbolik. Simbol-simbol yang mewakili mitosmitos yang selalu ingin dijaga oleh komunitas atau masyarakat dalam hal ini masyarakat Kaltim. Dalam analisis penelitian ini, mitologi tadi terekspresikan melalui prosesi adat sakral Beluluh Sultan. Hal tersebut memerlukan teori semiotik untuk menemukan pemaknaan dalam tanda-tanda yang terdapat dalam upacara tersebut sehingga diketahui fungsi ekspresif, kreatif, psikologi, dan sosialnya.

Semiotika Peirce menjelaskan hubungan yang argumentatif (sebab-akibat) antara ikon menjadi indeks sehingga memunculkan simbol dalam suatu upacara atau ritual yang berkaitan dengan penelitian ini adalah Prosesi Adat Beluluh Sultan. Dalam semiotika Peirce, dijelaskan tipe-tipe tanda seperti ikon, indeks, dan simbol memiliki nuansa-nuansa yang dapat dibedakan. Penggolongan yang berdasarkan pada hubungan kenyataan dengan jenis dasarnya itu melihat atas pelaksanaan fungsi sebagai tanda. Simbol-simbol yang terdapat dalam ritual mewakili mitos yang senantiasa dipertahankan oleh masyarakat adat Kutai untuk memperkenalkan identitas dirinya, seperti salah satu bagian dari Prosesi Adat Beluluh Sultan yaitu tambak karang yang merupakan ukiran terbuat dari beras warnawarni. Tambak karang yang dibuat untuk pelaksanaan adat tersebut didasarkan pada mitologi munculnya bayi perempuan yaitu Putri Karang Melenu di Sungai Mahakam setelah seekor naga yang dipelihara oleh Petinggi Hulu Dusun diturunkan ke sungai tersebut, pembuatan tambak karang dengan demikian merupakan representasi mitos naga sebagai totem dari Putri Karang Melenu yang turun ke Sungai Mahakam. Sementara itu, ritual ketika Sultan duduk di balai 41 merupakan media perwujudan lahirnya Putri Karang Melenu dan di Erau-kan. Dengan menemukan makna simbol-simbol yang terdapat dalam keseluruhan Prosesi Adat Beluluh Sultan, keterkaitan antara mitos dengan ritual tersebut dapat dijelaskan secara empiris.

Dengan demikian, masyarakat penganutnya dapat dikatakan masyarakat religius yang menerima adanya Hakikat Tertinggi sebagai Penguasa Tertinggi pula. Hakikat Tertinggi, Tuhan, Pencipta alam semesta, menyatakan diri melalui ciptaan-Nya. Disinilah operasionalisasi (tahap-tahap) semiotik Pierce untuk menjelaskan upacara mitologis, dalam hal ini Prosesi Adat Beluluh Sultan sebagai bentuk pensucian diri Sultan yang mengambil dasar cerita mitos lahirnya Putri Karang Melenu. Kelahiran bayi (Putri Karang Melenu) diibaratkan sesuatu yang suci tanpa dosa.

\section{Fungsi Simbolik Adat Beluluh Sultan pada Perayaan Erau sebagai Media Perwujudan Mitologi Kisah Putri Karang Melenu}

Media perwujudan kisah Putri Karang Melenu ke dalam Prosesi Beluluh Sultan tidak hanya sekadar menjadi upacara adat semata dan menjadi satu-satunya ritual sakral. Melalui upacara adat ini, beberapa ritual adat tercover di dalamnya. Selain itu, terdapat beberapa fungsi dalam ritual ini yang berkaitan dengan ritual lainnya. Fungsi-fungsi tersebut, yaitu: fungsi ekpresif, fungsi kreatif, fungsi psikologi, dan fungsi sosial. Fungsi-fungsi tersebut lebih lanjut dijelaskan berikut ini.

\section{Fungsi Ekspresif Perwujudan Kisah Putri Karang Melenu}

Perwujudan kisah Putri Karang Melenu sebagai dasarProsesi Beluluh Sultan memberikan gambaran empiris mengenai permulaan Kesultanan Kutai Kartanegara pada masyarakat Kutai khususnya, serta menunjukkan pada masyarakat lain yang juga ikut serta mendiami 
wilayah Kalimantan Timur umumnya. Kisah Putri Karang Melenu membantu dalam memaknai simbol-simbol dalam prosesi tersebut. Kisah Putri Karang Melenu sebagai mitos merupakan Indeksikalitas (objek) yang diimitasi oleh masyarakat adat Kutai melalui persamaan kisah tersebut ke dalam Prosesi Beluluh Sultan terdapat tiga subbagian cerita, pertama menceritakan kisah naga (totem) dari Putri Karang Melenu. Kedua, fenomena alam terjadi saat kemunculan Putri Karang Melenu yang masih bayi, dan ketiga menceritakan Putri Karang Melenu dieraukan.

Ritual menjadi sebuah ikon (representamen) yang dalam keseluruhan proses terdapat bentuk persamaan naga (totem) dari Putri Karang Melenu dan fenomena alam yang terdapat dalam kisah kemunculan (kelahiran) Putri Karang Melenu, digambarkan dalam ukiran beras warnawarni (tambak karang). Selanjutnya, bagaimana persamaan balai 41 , tempat duduk Sultan saat diritualkan sebagai ikon yang menceritakan kemunculan Putri Karang Melenu dan saat ia dieraukan. Ikon di sini dipercaya bersifat sakral dalam dirinya. Oleh karena itu, dapat menuntun pengikut ritual bersangkutan untuk mengadakan kontak dengan sosok yang diwakilinya yaitu Putri Karang Melenu (melalui naga sebagai totemnya).

Sementara itu, pada simbol (interpretan) ditampilkan hubungan antara ikon dan indeks. Dalam hal ini, hubungan antara keseluruhan Prosesi Adat Beluluh Sultan mulai dari ukiran tambak karang sampai prosesi Beluluh untuk Sultan dilakukan (termasuk perlengkapan ritual dan mantra) dengan kisah kelahiran Putri Karang Melenu yang tidak dapat dipisahkan. Hal tersebut dapat memiliki fungsi ekspresif dari keseluruhan rangkaian ritual yang dijabarkan dalam tahapan-tahapan berikut.

\section{- Pembuatan Tambak Karang}

Pembuatan tambak karang merupakan salah satu wujud ekspresi masyarakat adat secara empiris menggambarkan kisah mendasar dibalik Prosesi Beluluh Sultan. Tambak karang juga merupakan ekspresi seni ukir masyarakat adat yang bahan pembuatannya dari beras yang diwarna warni menggunakan zat pewarna.

Dalam pembuatan tambak karang, ketua pembuat tambak karang telah mendapatkan arahan terlebih dahulu dari Pemangku Adat Sakral, Awang Imaluddin. Dengan demikian, diharapkan tidak terdapat kesalahan penempatan pada pembuatan tambak karang.

Penempatan tiap-tiap bentuk ukiran tidak boleh sampai salah, warna yang digunakan pada setiap ukiran harus seimbang, namun ada tiga ukiran yang pewarnaannya tidak boleh diganti dengan warna lain. Dengan masih memperhatikan nilai estetika, pembuat tambak karang juga masih memperhatikan penempatan ukiran, seperti ukiran taman.Dalam pemikiran masyarakat umum, taman menggambarkan halaman rumah maka penempatannya akan selalu berada di depan tidak boleh di belakang. Sementara itu, ukiran kolam menggambarkan sungai bagi masyarakat umum dalam hal ini masyarakat Kutai, harus di tempatkan di belakang.

Hal tersebut dimaksudkan bahwa halaman tempat orang menerima tamu dan bercengkrama dengan orang lain harus melewati depan rumah, sedangkan sungai tempat orang melakukan segala aktivitas rumah tangga mulai dari mencuci, mandi, dan sejenisnya harus diletakkan di belakang. Dengan demikian, pemikiran umum tersebut sama halnya dengan pemikiran masyarakat adat yang menempatkan taman di bagian depan menghadap ke luar halaman kedaton, sementara kolam berada di bagian belakang saat Beluluh Sultan. Gambar 1 merupakan salah satu contoh penempatan taman diletakkan di bagian depan.

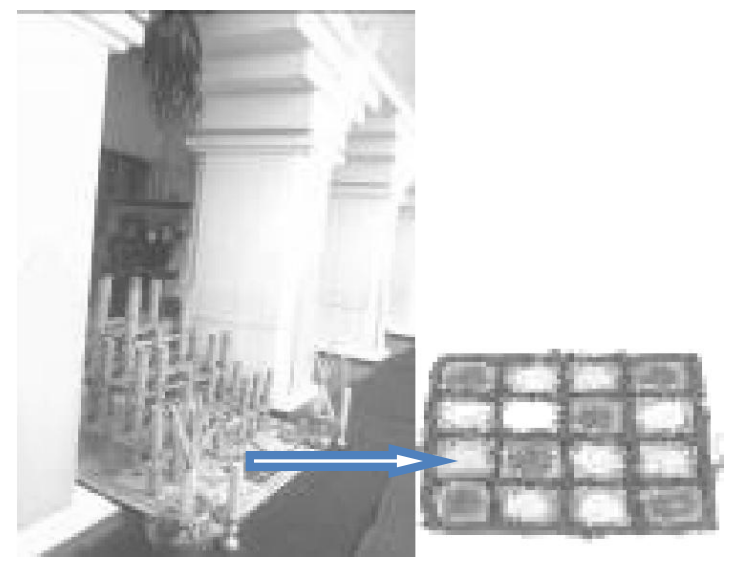

Gambar 1.

Ukiran taman setelah bale 41 diletakkan di atasnya (Sumber: dokumen pribadi peneliti)

Berdasarkan gambar 1 dapat dilihat posisi taman setelah balai 41 diletakkan di atasnya, dapat dilihat posisinya menghadap ke depan di mana Sultan nanti akan duduk dan menghadap ke halaman kedaton. Hal ini mengekspresikan posisi Sultan ketika menghadapi (bisa dikatakan menyambut) masyarakatnya saat Beluluh. 
Selain penempatan yang tidak boleh diganti-ganti, beberapa ukiran juga memiliki warna yang tidak boleh diganti-ganti pula yaitu ukiran kolam selalu berwarna biru di tengahnya seperti halnya warna air yang terkena pantulan langit berwarna biru. Hal ini secara empiris juga terdapat dalam dunia profan manusia. Kemudian ukiran pelangi yang memiliki warna dasar merah, kuning, dan hijau sama seperti warna pelangi dalam dunia profan memiliki warna dasar yang sama. Sementara itu, jembatan yang menjadi salah satu ukiran dalam tambak karang memiliki warna yang sama dengan pelangi. Hal tersebut dimaksudkan sebagai unsur keseimbangan antara pelangi dan jembatan yang ukirannya berdekatan seperti gambar 2 .

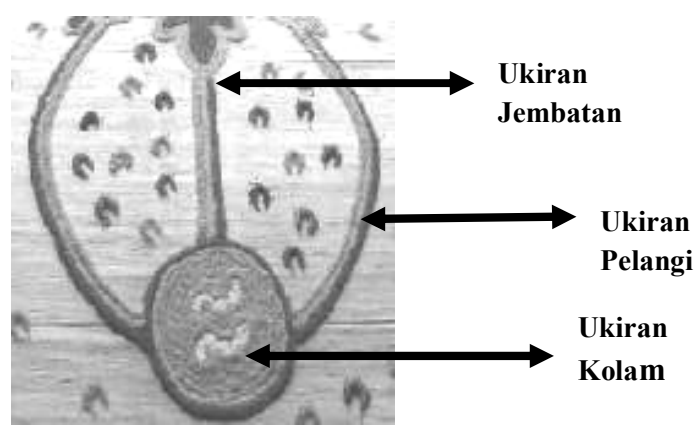

Gambar 2

Bagian ukiran tambak karang

(Sumber: dokumen pribadi peneliti)

Berdasarkan penjelasan-penjelasan tersebut, pembuatan tambak karang secara ekspresif merupakan bentuk dari implikasi imitasi imajinatif masyarakat adat terhadap kisah Putri Karang Melenu. Pembuatan tambak karang tersebut juga masih memikirkan nilai estetik dan beberapa logika alam serta keseharian manusia seperti yang telah dicontohkan sebelumnya.

\section{- Pelaksanaan Prosesi Beluluh}

Pelaksanaan prosesi Beluluh menunjukkan suatu pola gerak ritual dalam mengimitasi kesucian kisah Putri Karang Melenu saat kelahirannya. Belian sebagai pemimpin upacara sakral membacakan mantra yang dapat dikatakan juga sebagai doa kepada Tuhan untuk memohon segala kebaikan dan dihindarkan dari segala keburukan.

Doa yang dipanjatkan Belian tertuang dalam makna mantra Beluluh Sultan. Mulai dari pembuka, mantra ini memiliki empat tahapan, yaitu: pengangungan terhadap Tuhan Yang
Maha Esa, permohonan ampun, penyampaian maksud, dan pengharapan. Tahap pertama, pengangungan atas Tuhan Yang Maha Esa merupakan bentuk ketaatan manusia kepada sang pencipta. Dengan selalu mengingat-Nya setiap kali akan melakukan aktivitas, manusia dapat terus melakukan kegiatan dengan lancar. Kata "Waaan Cahololooo" merupakan kata yang mengawali mantra ini dan merujuk pada Tuhan.

Setelah pengangungan atas Tuhan YME, secara ekspresif, mantra ini dilanjutkan dengan permohonan ampun melalui rangkaian kata "ampun beribu ampun maaf beribu maaf, ampun tolong diampuni, maaf tolong dimaafkan". Permohonan ampun merupakan hal yang akan dipanjatkan dalam setiap doa karena manusia tidak lepas dari kesalahan baik yang terdahulu, sekarang, ataupun yang akan datang. Manusia perlu dan penting mengingatkan bahwa dirinya memerlukan pengampunan dari sang pencipta tentang segala sesuatunya sebagai pendahuluan sebelum melakukan aktivitas ataupun permintaan. Pengulangan kata ampun dan maaf yang berkalikali sebagai bentuk kesungguhan hati dalam memohon pengampunan menunjukkan bahwa manusia atau pelaku ritual tersebut tidak setengah-setengah dalam mengharapkan sesuatu dari sang pencipta.

Pengharapan dalam mantra tersebut diungkapkan pula oleh manusia yaitu berupa hajat yang diharapkan dapat dikabulkan oleh sang pencipta. Pelaku ritual (masyarakat adat) yang memiliki hajat melalui mantranya dapat dikatakan menyampaikan maksud hajatnya kepada sang pencipta untuk senantiasa dikabulkan pengharapan dan dihindarkan dari segala musibah yang ditandai dengan kata-kata "mau memeriahkan perayaan ke kediaman Sultan". Perayaan yang dimaksud adalah pesta rakyat "Erau", termasuk Beluluh di dalamnya dan berbagai aktivitas lainnya (lihat lampiran jadwal acara Erau) dan penekanan kata "jangan menyuruh" berulang kali bukan sebagai kata perintah seperti dalam bahasa Indonesia. Kata tersebut lebih bermakna mitis yaitu bentuk pengharapan yang sungguh-sungguh dari pelaku ritual terhadap sang pencipta agar dalam pelaksanaan ritual tidak terjadi musibah apapun seperti "tidak ada pembunuhan, tidak ada orang mati muda". Hal ini menunjukkan bahwa pelaku ritual memahami bahwa sekuat apapun mereka dan dengan teknologi modern sekalipun, tidak ada yang dapat mengalahkan kekuatan sang pencipta sehingga pengharapan terbesar akan 
senantiasa ditujukan kepada-Nya. Dengan demikian, mantra sebagai salah satu sarana ekpresif masyarakat adat dalam berdoa untuk memohon segala sesuatu akan kelancaran ritual Beluluh Sultan yang dianggap memiliki nilai kesucian serta sakral kepada Tuhan YME memiliki peranan penting.

Begitupun gerak dari dewa ketika menepong tawari, tepong tawar sebagai bentuk imitasi dari bayi Putri Karang Melenu yang dianggap masih suci belum ternoda oleh dosa apapun. Hal tersebut dianggap sebagai cara mensucikan diri atau tubuh Sultan dari najis atau kotoran yang menempel di tubuhnya maupun dari hal-hal yang tidak baik (dapat dilihat pada beberapa contoh gambar di bawah ini). Bentuk pensucian dapat bermacam macam, contoh pada orang Islam ketika akan melaksanakan ibadah dengan cara berwudhu. Hal tersebut mempunyai fungsi yang sama untuk mensucikan diri walaupun bentuk atau tata cara pensuciannya berbeda.

Tepong tawar ini dalam pelaksanaan Beluluh dipercikan oleh belian sambil membacakan mantra Beluluh. Setelah belian melakukan tepong tawar, dewa (ahli mantra perempuan) selanjutnya menepong tawari Sultan, pertama dimulai dari tangan, kedua bahu Sultan, kemudian kaki Sultan. Hal tersebut dapat dimaknai sebagai bentuk pembersihan indra atau tubuh Sultan dari kotoran-kotoran yang mungkin melekat pada tubuhnya. Namun juga, dari urutan tangan yang ditepong tawari meyimbolkan pensucian diri Sultan dalam memimpin atau mengendalikan kekuasaan agar terbebas dari terhindar dari hal yang tidak baik. Kedua adalah bahu Sultan menyimbolkan kesucian atau kebersihan diri dalam mengemban amanat kekuasaannya. Terakhir, kaki Sultan yang ditepongtawari meyimbolkan tujuan dalam mengantarkan atau melangkahkan gerak kegiatan Kesultanan Kutai bagi masyarakatnya. Selain itu, kaki juga dapat dimaknai sebagai penopang. Hal tersebut tidak hanya diartikan sebagai penopang tubuh, tetapi dalam tampuk kepemimpinan Sultan diharapkan dapat menjadi penopang yang kuat bagi Kesultanan Kutai Kartanegara dan wilayah kekuasaannya.

Tidak hanya tepong tawar sebagai bentuk ekpresif kesucian tersebut, Sultan membasuh kepala dengan air bunga dan air pemadam juga memiliki makna. Air dicampur dengan bunga yang dibasuh ke kepala Sultan sebagai maksud untuk membersihkan diri dari pemikiran-pemikiran yang tidak baik. Hal tersebut menandakan bahwa Sultan juga manusia biasa yang tidak luput dari salah seperti penggambaran bunga itu sendiri yang terkadang tumbuh, layu, dan tumbuh kembali serta layu kembali. Dengan demikian, air bunga juga menjadi simbol pensucian diri Sultan dari berbagai hal yang tidak baik. Sementara itu, air pemadam menyimbolkan kebersihan hati tanpa memandang tingkatan atau golongan. Sultan dalam hal ini diharapkan dapat melihat semuanya dengan jernih tanpa memihak satu golongan atau tingkatan sosial saja. Semua golongan atau tingkatan sosial akan mendapatkan perhatian yang sama tanpa dibeda-bedakan.

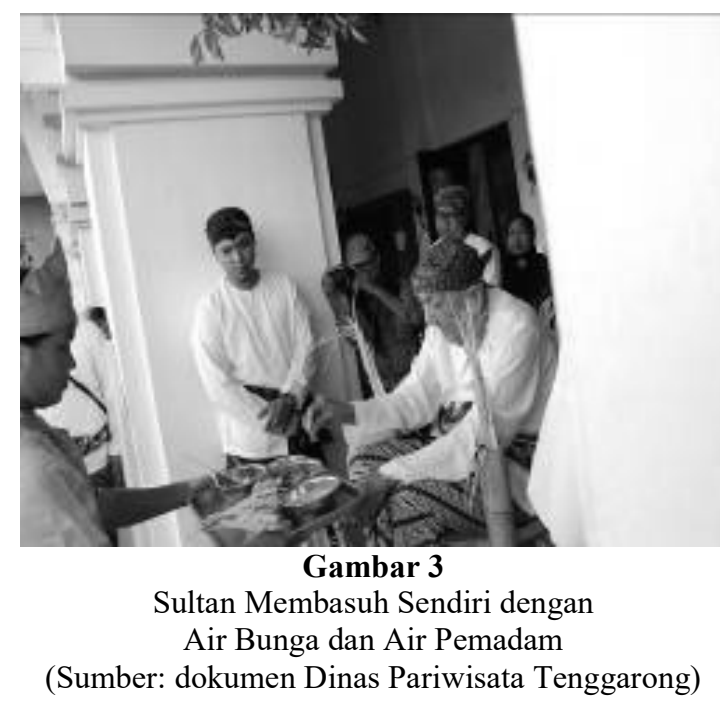

Selesai, Sultan disucikan, Sultan menarik ketikai lepas dengan tokoh masyarakat, pejabat pemerintahan, maupun kerabat kesultanan sendiri. Hal tersebut mengekspresikan bentuk kemenangan setelah sebelumnya disucikan. Kegiatan ini pun kurang lebih sama dalam agama Islam ketika telah menjalankan ibadah misalnya puasa di bulan Ramadhan. Untuk menyambut kemenangan, kebanyakan di rumah orang Islam tersedia ketupat dan segala macam masakan yang bulan puasa tidak setiap hari dapat dinikmati dan juga dapat dimakan sewaktu waktu, harus menunggu waktu berbuka. Begitu pun penarikan ketikai lepas, itu hanya dapat dilakukan setelah upacara Beluluh, sama halnya penaburan beras tambak karang yang meng- gambarkan kemenangan dan keberkahan atas apa yang sudah dilaksanakan. 


\section{Fungsi Kreatif Perwujudan Kisah Putri Karang Melenu}

Prosesi Adat Beluluh Sultan sebagai wujud representasi kisah Putri Karang Melenu ini menunjukkan usaha masyarakat adat untuk menciptakan keseimbangan antara manusia dengan pencipta, manusia dengan manusia, dan manusia dengan alam sekitarnya agar senantiasa hidup tentram dan terbebas dari segala macam keburukan. Selain itu, secara kreatif dengan masih melestarikan tradisi Beluluh ini, masyarakat adat menunjukkan bahwa pemerintah Kesultanan Kutai masih ada dan masih berdiri kokoh dengan silsilah dan adat yang terus dipegang dari keturunan sebelumnya. Hal tersebut diperlihatkan dengan masih terjaganya ritual sakral Prosesi Beluluh Sultan pada setiap upacara adat Erau tiap tahunnya sebagai simbol khusus bagi pimpinan Kesultanan Kutai yang berkuasa yang menggambarkan keturunan kuat dari Putri Karang Melenu, ibu dari Sultan-sultan Kutai Kartanegara Ing Martadipura dan hal tersebut dalam pelaksanaannya tidak boleh digantikan kepada orang lain dalam keadaan apapun.

Prosesi ini hanya dikhususkan untuk Sultan Kutai Kartanegara Ing Martadipura yang berkuasa saat itu sebagai simbol kekuatan silsilah dan adat yang harus dijunjung tidak hanya oleh keluarga kesultanan tetapi juga masyarakatnya. Walaupun nampak ideologi feodal masih ada, hal tersebut adalah cara suatu daerah untuk dapat membangun daerahnya tanpa menghilangkan kebudayaan yang dimiliki dan dapat terus menjunjung harkat dan martabat lokalnya sehingga tidak akan musnah tergerus oleh budaya-budaya pendatang. Fungsinya sebagai arahan, capaian Kesultanan Kutai Kartanegara bagi kelangsungan kebudayaannya untuk dapat dilestarikan.

Prosesi ini merupakan prosesi sakral karena mitos kisah kemunculan Putri Karang Melenu sebagai seorang bayi yang dimulai dari turunnya ular naga ke Sungai Mahakam sampai menginjakkan kaki ke tanah pertama kali. Prosesi sakral ini selalu ada dan juga sebagai penanda perayaan Erau di Tenggarong. Hal tersebut dikarenakan kisah Putri Karang Melenu merupakan akar penguat atau pengukuh kedudukan Sultan Kutai Kartanegara Ing Martadipura sebagai pemilik adat sekaligus penguasa adat budaya di wilayah Tenggarong dan beberapa willayah adatnya yang lain di Kalimantan Timur.
Gambaran kisah Putri Karang Melenu yang dianggap sebagai ibu yang menurunkan raja-raja Kutai Kartanegara Ing Martadipura dengan kelahirannya yang tidak biasa dalam artian sebagai sosok yang kehadirannya memiliki daya magis atau dalam kepercayaan masa lalu merupakan keturunan dewa adalah sesuatu yang sangat sakral. Hal tersebut juga memperlihatkan kedudukan utama dan penting bagi keturunanketurunannya di Kesultanan Kutai Kartanegara sebagai penguasa adat di Tenggarong khususnya dan wilayah adat lain di Kalimantan Timur umumnya. Dengan demikian, tindak lanjut penguatan akan kedudukan tersebut sangat penting dan apresiasi dalam mewujudkannya secara nyata dengan merepresentasikan kisah tersebut dalam bentuk prosesi adat, yang dalam hal ini prosesi adat sakral tersebut adalah Beluluh Sultan.

Kesakralan kedudukan seorang sultan sangat nampak dalam tiap tahapan upacara mulai dari ukiran karang yang digunakan sampai balai tempat dudukan sultan dan pada saat sultan dibasuh dengan air. Sultan diibaratkan bayi yang baru lahir dalam keadaan suci dengan dikelilingi pengikutnya dan dijunjung pada kedudukan tertinggi sebagai pemimpin wilayah Kesultanan Kutai Kartanegara Ing Martadipura yang ada dan masih menjalankan adat budaya leluhur sebagai penguat kedudukannya digambarkan dalam sketsa posisi tempat Sultan saat ritual.

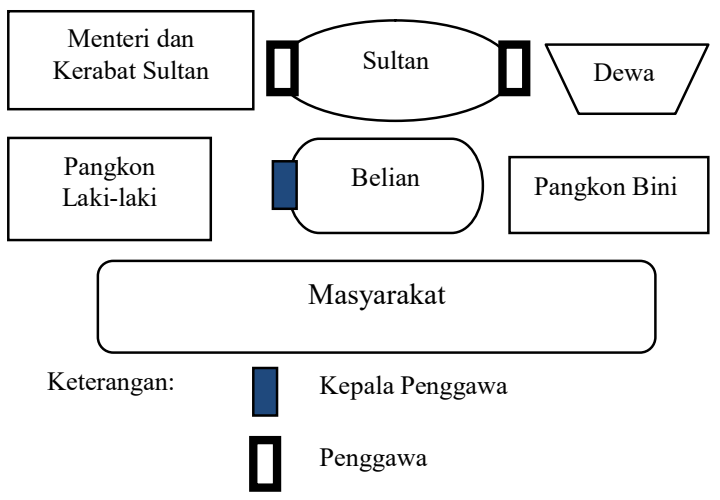

Media perwujudan kisah Putri Karang Melenu dalam Prosesi Adat Beluluh Sultan jelas memiliki manfaat bagi pemilik adat khususnya dan masyarakat umum di sekelilingnya pada umumnya. Manfaat dalam hal ini merupakan keuntungan ataupun kegunaan yang didapatkan dari Prosesi Adat Beluluh Sultan sebagai bentuk perwujudan kisah Putri Karang Melenu. Lebih lanjut, manfaat tersebut, yaitu: 


\section{- Masyarakat Mengenal Akar Budaya Kesultanan Kutai Kartanegara Ing Martadipura}

Dengan media perwujudan kisah Putri Karang Melenu ke dalam bentuk ritual adat, masyarakat di sekitarnya dapat mengenal asal atau identitas Kesultanan Kutai Kartanegara sehingga tidak kabur dan dapat ikut membantu melestarikannya. Akar budaya tersebut sangat penting mengingat kemajemukan penduduk di wilayah Kesultanan Kutai Kartanegara yang tidak semua mengetahui kisah tersebut. Kisah itu pun dikuatkan dalam ritual mengulur naga yang merupakan totem dari Putri Karang Melenu di hari terakhir perayaan Erau. Oleh karena itu, memperkenalkan akar budaya berupa kisah sakral Putri Karang Melenu dalam bentuk Prosesi Adat Beluluh Sultan dengan berbagai ritual lainnya yang terkait dengan kisah tersebut akan memberikan pandangan bahwa prosesi ini memiliki makna sangat penting dan merupakan identitas Kesultanan Kutai Kartanegara dalam membangun wilayah adatnya.

Dalam Beluluh Sultan yang menceritakan kisah Putri Karang Melenu diawali dari ukiran tambak karang yang mengisahkan totemnya yaitu ular naga. Tambak karang dilihat dalam motif umumnya menggambarkan kisah naga yang turun ke sungai dan pada akhirnya memunculkan Putri Karang Melenu yang ditunjukkan dalam ukiran naga pada setiap sisinya, ukiran tangga sebagai penggambaran alat yang digunakan naga untuk turun ke sungai, kolam sebagai sungai tempat naga diturunkan, ukiran buih yang timbul setelah naga diturunkan ke sungai, ukiran pelangi setelah peristiwa alam mereda, dan ukiran taman sebagai penggambaran bunga-bunga yang muncul di pinggiran sungai Mahakam. Motif-motif tersebut selalu ada dalam pembuatan tambak karang keseluruhan. Hal tersebut dikarenakan motif-motif tersebut merupakan dasar dari media perwujudan kisah Putri Karang Melenu pada salah satu bagian Prosesi Beluluh Sultan.

Sementara itu, totem dari Putri Karang Melenu tersebut selanjutnya diimitasi lagi ke dalam bentuk patung naga yang nantinya diturunkan ke Tepian Batu. Tepian Batu merupakan tempat yang dipercaya sesuai mitos turunnya naga ke Sungai Mahakam dalam kisah kelahiran Putri Karang Melenu dalam lampiran naskah kuno hlm. 10 (Sayekti, 2010). Oleh karena itu, tempat tersebut menjadi sangat sakral bagi masyarakat adat. Beluluh Sultan yang merepresentasikan kisah Putri Karang Melenu dengan jelas memberikan gambaran tersebut dalam tambak karang serta tempat patung naga diturunkan sesuai dengan kisah naga yang turun ke Sungai Mahakam di Kutai lama dan berikutnya memunculkan Putri Karang Melenu. Dengan alur tersebut, masyarakat adat dapat menguatkan dan membuat masyarakat umum memahami maksud dari Prosesi Beluluh Sultan. Bentuk imitasi ini merupakan wujud kreatifitas dari masyarakat adat untuk memperkenalkan identitas Kesultanan Kutai kepada masyarakat umum.

Proses kreatif tersebut tidak berhenti pada pembuatan patung naga yang nantinya diulur ke Tepian Pandan, tetapi proses kreatif tersebut juga dimunculkan dalam bentuk mantra. Mantra sebagai bagian dari Beluluh Sultan merupakan bentuk perkataan atau ucapan yang diyakini memiliki kekuatan gaib. Melalui mantra ini, tata cara dan maksud dari Beluluh Sultan dijelaskan seperti pelaksanaan dan maksud tepong tawar dalam Beluluh Sultan.

Tepong tawar merupakan salah satu aplikasi dari mantra tersebut menjelaskan tata cara dalam Beluluh Sultan dengan maksud mensucikan diri sultan dan menghindarkan dari segala hal buruk. Kata "puntawar" yang merujuk pada pelaksanaan tepong tawar dalam mantra ini berasal dari kata tawar. Kata tawar dapat bermakna tidak berasa apapun belum terkontaminasi dengan rasa apapun baik manis, pahit, asin, asam, seperti makanan pada bayi yang tidak memiliki rasa apapun di awal pertumbuhannya. Tawar dapat pula bermakna sebagai obat atau penangkal dari suatu penyakit, bencana dan racun. Oleh karena itu, tepong tawar dalam ritual ini merupakan bentuk aplikasi kreatifitas dalam menyampaikan maksud atau makna dibalik mantra Beluluh Sultan yaitu memberikan penangkal agar tidak terjadi sesuatu yang buruk selama perayaan adat di Kesultanan Kutai Kartanegara baik yang diakibatkan oleh manusia maupun dari alam dan dapat diartikan pula sebagai bentuk menata ulang segala pikiran dan tindakan yang mulai mengalami gangguan karena terkontaminasi sesuatu yang buruk agar kembali dapat menjadi jernih dan baik.

Bentuk kreatif lain yang memiliki makna tersirat dalam mantra Beluluh Sultan disebutkan mengenai "ayu". Kata "ayu" dapat diumpamakan sebagai simbol pegangan hidup 
masyarakat Kutai dan sekitarnya di bawah Kesultanan Kutai Kartanegara. Pedoman itu penting diketahui dan sekaligus diharapkan dapat dipahami pula oleh masyarakat Kutai dan sekitarnya. Pedoman atau tata aturan itu merupakan tata aturan di wilayah Kutai (berhubungan dengan hak ulayat tanah) baik bagi kerabat kesultanan sendiri (masyarakat adat) maupun masyarakat Kutai dan sekitarnya (masyarakat umum yang tinggal di wilayah Kutai) agar dapat sama-sama menjaga dan menaati aturan adat istiadat di wilayah tersebut. Dalam wujud ritual, pedoman ini diaplikasikan secara kreatif pada tiang ayu sebagai simbol.

Pedoman tersebut dapat dikatakan sebagai undang-undang di Kesultanan Kutai yaitu Kitab Undang-Undang Kesultanan Kutai Kartanegara Ing Martadipura "Panji Selaten" terdiri dari 39 pasal dan Undang-Undang Braja Niti (Maharaja Nanti) terdiri dari 164 pasal yang telah turuntemurun menjadi acuan bagi Kesultanan Kutai dalam menjalankan roda pemerintahan terhadap adat di wilayahnya. Undang-undang tersebut pertama memuat dasar negara Kesultanan Kutai Kartanegara Ing Martapura yaitu berdasarkan Hukum Islam dan Hukum Adat yang dituangkan dalam Panji Selaten. Kedua, Organisasi Pemerintah yang sifatnya dapat mengatur tata kehidupan raja, para petugas kesultanan dan hak-hak serta kewajiban yang harus dijalankan oleh rakyat. Ketiga, sifat pemerintahan berdasarkan Undangundang Panji Selaten terbuka karena undangundang ini satu-satunya landasan yang menjamin hak setiap warganya di dalam perjalanan kesultanan itu untuk mencapai kesentausaan dan kemakmuran bagi negerinya (Kutai, 2003).

Pedoman yang dianggap mulai renggang atau longgar dan menyimpang perlu dilekatkan atau ditata ulang dan diluruskan kembali. Hal itu juga disampaikan dalam mantra Beluluh ini dengan penjelasan berdasarkan kata "suta benang" yang merupakan alat pengikat berupa benang sutera. Benang sutera yang dimaksud dalam aplikasi ritual berupa tali juwita. Tali yang dibuat dari benang $3 \times 7$ helai lalu dikuningi dengan kunyit. Jika dikalikan, kedua angka tersebut berjumlah 21(dua puluh satu) dan jika ditambah hasilnya menjadi 3 (tiga). Jumlah tersebut sama dengan makna dari balai 41 . Angka tiga bermakna bahwa setiap apapun di dunia ini pasti mengalami tiga hal yaitu awal, tengah, dan akhir. Sementara itu, dalam Pancasila, angka 3 (tiga) sebagai pemersatu yang berbunyi 'Persatuan Indonesia'. Bentuk lain aplikasi dari benang sutera dalam ritual Beluluh ini adalah Kain Cinde. Penggunaan Kain Cinde selain sebagai simbol pengingat kelahiran Putri Karang Melenu, kain ini merupakan alat perantara dalam menuju dunia gaib dalam kepercayaan masyarakat adat agar semua kegiatan berjalan dengan baik tidak terjadi bencana. Keduanya diikatkan pada tiang ayu sebagai simbol bahwa masih erat dan kuatnya pedoman tersebut di wilayah Kutai.

Jika pedoman tersebut tidak dijaga dan dilestarikan dengan maksimal, kepunahan akar atau jati diri dari masyarakat Kutai dan sekitarnya serta Kesultanan Kutai Kartanegara akan terjadi. Hal tersebut dapat mengakibatkan penderitaan banyak orang di wilayah Kutai karena tata kehidupan sudah tidak lagi baik bagi kehidupan bermasyarakat maupun keseimbangan dengan alam. Masyarakat di sekitar wilayah Kesultanan Kutai baik kerabat kesultanan sendiri (masyarakat adat) maupun masyarakat Kutai dan sekitarnya (masyarakat umum yang tinggal di wilayah Kutai) harus tetap menjaga adat istiadat tersebut. Dengan masih memegang pedoman tersebut, Kesultanan Kutai dapat terus menjaga keseimbangan dan melestarikan adat budaya, wilayah, dan masyarakatnya tetap damai dan hidup sejahtera.

Dengan demikian, fungsi kreatif ritual Beluluh Sultan ini sangat kompleks. Tidak hanya mengenalkan akar budaya Kutai berupa identitas Kesultanan Kutai berasal, ritual Beluluh ini juga memperkenalkan pedoman atau tata aturan kehidupan di wilayah Kutai yang tertuang dalam Undang-Undang "Panji Selaten" dan UndangUndang Braja Niti (Maharaja Nanti). Selain itu, ritual Beluluh secara kreatif merangkum sekaligus menghubungkan antar ritual satu dengan lainnya dalam mantranya yang memiliki tujuan untuk tetap melestarikan dan menjaga adat serta mewujudkan persatuan dan kedamaian di wilayah Kutai yang multikultural.

\section{- Meningkatkan Pariwisata Daerah Tenggarong}

Prosesi Adat Beluluh Sultan merupakan salah satu upacara sakral yang menandai pesta rakyat Kutai "Erau". Dalam pesta ini, seluruh penduduk tenggarong ikut memeriahkan. Begitupun Pemerintah Kota Tenggarong, melalui dinas pariwisata, pemerintah kembali menggelar International Folk \& Art Festival (EIFAF) 2015 dan sekaligus festival daerah. Hal ini bukanlah kali pertama Kesultanan Kutai Kartanegara 
membaur menjadi satu dengan masyarakat baik dalam negeri maupun luar negeri.

Keterbukaan Kesultanan Kutai terhadap budaya dari luar Kutai baik dari seluruh suku di Indonesia maupun dari luar Indonesia telah lama berlangsung. Keterbukaan itu ditunjukkan salah satunya dari pakaian adat yang dimiliki oleh Kesultanan Kutai baik pada ritual Beluluh maupun ritual lainnya. PakaianMiskat dan Pesapu, misalnya, pakaian tersebut memiliki perpaduan dengan budaya luar. Miskat memiliki kemiripan dengan pakaian Cina digunakan sebagai baju biasa sehari-hari dan disain mirip baju dari Korea menunjukkan perkembangan budaya Kutai pada zaman dulu sangat besar serta menyimbolkan kejayaan Kesultanan Kutai dengan pecampuran dua budaya berbeda. Sementara itu, Baju Adat Pesapu merupakan pakaian adat yang biasa digunakan pada ritual di luar kedaton, berupa atasan warna putih dipadukan dengan celana panjang batik dan sarung yang diikatkan dipinggang serta tutup kepala dari batik yang diikatkan sedemikian rupa di kepala merupakan perpaduan dari Jawa mengingat masih adanya sejarah hubungan Kutai dengan Jawa. Hal itu menandakan bagaimana kerja sama antar daerah di luar pulau telah terjalin sampai pada perpaduan tata busana.

Oleh karena itu, pemerintah Kota Tenggarong tidak salah dalam menggelar kembali festival budaya ini dengan melihat bagaimana Kesultanan Kutai sebagai suatu kesultanan yang memiliki keterbukaan terhadap budaya dari luar sehingga melalui festival ini semakin mempererat kerja sama dengan daerah atau negara lain dalam bidang pariwisata. Dengan demikian, Pemerintah Kota Tenggarong melalui kreasinya dalam bentuk kegiatankegiatan tersebut selain ikut melestarikan kebudayaan yang di dalamnya terdapat adat sakral Prosesi Beluluh Sultan, sekaligus memperkenalkan kebudayaan Kutai terhadap masyarakat dari mancanegara yang memiliki keanekaragaman karena perpaduan budaya yang sejak zaman dulu telah berkembang di Kesultanan Kutai. Hal tersebut diharapkan dapat meningkatkan pariwisata Kota Tenggarong tidak hanya di dalam, namun juga dari luar negeri. Terutama, Bulan Juni menjadi waktu yang tepat untuk mempromosikan kebudayaan Kota Tenggarong. Menurut Pemangku Adat Sakral, mengapa pelaksanaan acara diadakan di bulan Juni, hal tersebut dikarenakan di bulan tersebut merupakan musim pariwisata di mana banyak masyarakat luar negeri akan melakukan perjalanan liburan ke negara lain.

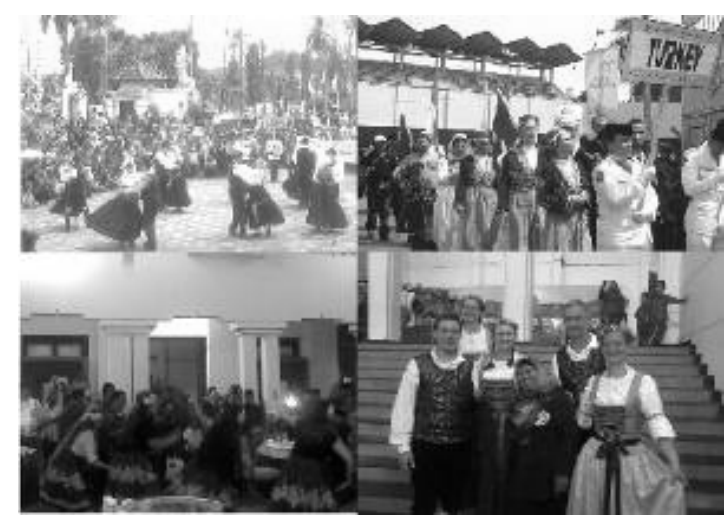

Gambar 4

Peserta International Folk \& Art Festival (EIFAF) 2015 dari mancanegara

(Sumber: dokumen peneliti pribadi)

Kegiatan tersebut tahun ini diikuti Kutai Kertanegara (Kukar) dan 17 negara yakni Bulgaria, Hongaria, Estonia, Latvia, Slovenia, Jerman, Polandia, Italia, Rusia, Mesir, Afrika Selatan, Malaysia, Filipina, Turki, Korea Selatan, Venezuela, dan Amerika Serikat. Sementara itu, 30 paguyuban/sanggar seni di Kutai dari berbagai daerah juga ikut ambil bagian dalam festival. Diawali dengan kirab budaya di pusat Kota Tenggarong sampai ke halaman kedaton, para peserta festival memperkenalkan asal mereka dan tariannya.

\section{Fungsi Psikologis Perwujudan Kisah Putri Karang Melenu}

Fungsi psikologis prosesi adat ini memberikan ketenangan jiwa bagi para pengikutnya, dalam hal ini adalah masyarakat adat. Dengan telah dilakukan Beluluh Sultan baik pada pra Erau ataupun saat Erau dilaksanakan. Kegiatan-kegiatan adat yang lainnya baru dapat dilakukan. Kegiatan-kegiatan adat tersebut berupa ritual sakral lanjutan dari ritual Beluluh Sultan seperti yang tersirat dalam mantra Beluluh. Berdasarkan pelaksanaan Beluluh Sultan pra Erau dan saat Erau dilaksanakan, kegiatan-kegiatan ritual yang mengikuti pun dibagi dua.

\section{- Beluluh Sultan Pra Erau}

Beluluh Sultan pra Erau dilakukan sebelum perayaan dibuka. Beluluh ini tata cara pelaksanaannya sama halnya dengan Beluluh saat Erau berlangsung. Pembedanya hanya pada tempat, waktu, tambak karang, dan pengunjung 
yang datang. Beluluh pra Erau dilaksanakan pagi hari di dalam kedaton dan dihadiri oleh tamu undangan dari beberapa dinas pemerintahan Kota Tenggarong, tokoh masyarakat, kerabat kesultanan, serta beberapa tamu undangan lain. Tambak karang yang digunakan hanya satu jenis saja yaitu karang nungkul. Tambak karang nungkul merupakan tambak karang yang dikhususkan untuk sultan merupakan bentuk harapan dan perwujudan dari Kesultanan Kutai untuk memberikan kebermanfaatan seluruh aktivitas atau kegiatan yang dilakukan pada perayaan Erau bagi semua lapisan masyarakatnya. Jumlah kelopak tungkul ada tujuh memiliki keistimewaan dalam berbagai rutinitas ibadah, alam semesta, dan juga sejarah. Tatanan yang sempurna dengan basis angka tujuh dalam alqur'an juga menunjukan keesaan Allah dan alqur'an adalah kitabullah. Ketika menciptakan alam, Allah menjadikan langit berjumlah tujuh lapis, demikian juga bumi. Hal itu sangat sesuai dengan masyarakat Kutai yang mayoritas Islam yang tetap memberikan tempat atas keyakinannya saat ini sebagai wujud pengingat dan doa syukur kepada Allah. Oleh karena itu, Beluluh membawa ketenangan bagi masyarakat adat sehingga dapat melaksanakan ritual lainnya yang masih terkait dengan isi dari mantra Beluluh, yaitu:

\section{- Menjamu Benua}

Menjamu benua merupakan ritual mengundang "tamu" atau memberikan makan atau menjamu orang-orang halus yakni para kemumulan, kejuntaian, dan pengalasan. Secara simbolik, hal itu dilakukan masyarakat adat dalam mengingat leluhur sebagai bentuk rasa terima kasih atas identitas yang dapat mereka pertahankan sampai sekarang. Tempat-tempat para kemumulan, kejuntaian, dan pengalasan itu dalam mantra sebagian merupakan nama lama yang menjadi pusat kesultanan Kesultanan Kutai yaitu Tepian Pandan, Muara Jembayan, dan Kutai Lama. Sebagian lain, tempat-tempat yang disebutkan dalam mantra merupakan tempat yang menjaga raja zaman purba serta orang halus atau jin-jin yang menguasai Kutai dan diyakini oleh masyarakat adat bersemayam.

Berdasarkan keyakinan tersebut, pelaksanaan ritual ini diwakilkan pada tiga tempat di wilayah Tenggarong yaitu di kepala benua (daerah tanah merah, Mangkurawang), tengah benua (daerah depan museum Mulawarman, Kampung Panji), dan ekor benua (daerah depan kantor bupati tenggarong, Timbau). Ritual ini dilakukan oleh belian dan dewa dengan mempersiapkan sesajian di atas juhan dan trasak. Deskripsi kepala, tengah, dan ekor benua dapat berimplikasi pula pada kisah naga yang erat kaitannya dengan kelahiran Putri Karang Melenu. Secara psikologis, hal ini membantu masyarakat adat dalam mempertahankan dan menguatkan identitasnya sehingga tidak punah seiring perkembangan zaman dan masyarakat akan senantiasa berdamai dengan alam dengan ikut menjaga tempat-tempat tersebut dari kerusakan tangan-tangan jahil manusia.

\section{- Merangin}

Ritual merangin dilakukan belian dengan membacakan mantra yang sama dengan mantra Beluluh Sultan dan melakukan Tari Serapo Belian yang dilakukan bergantian dengan dewa yang menarikan tarian dewa memutari rumba. Merangin sebelum pembukaan Erau dilakukan tiga kali. Merangin I bertujuan untuk memberitahukan "orang-orang" yang ada di atas, Merangin II untuk memberitahukan "orangorang" yang ada di bawah, dan Merangin III merupakan edar Kutai, seluruh yang diberitahu diundang untuk duduk bersama-sama melaksanakan Erau.

Pemberitahuan tersebut dalam mantra Beluluh terdapat pada kata "nyata ka selegar sunghiyang asai sunghiyang tanah" yang memiliki arti memberitahukan kepada semua penunggu di atas penunggu tanah seperti maksud MeranginI dan II. Sementara itu, kata "nyata kampung pasopingan baris parombannan nyata kulalu ka selegar minak kajuntaayan ampok ka lalungngan" yang memiliki arti di kampung makhluk gaib yang jadi penjaga, memberitahukan ke roh nenek moyang-nenek moyang pelindungnya dalam mantra Beluluh sama seperti maksud Merangin III.

Secara psikologis, mantra Beluluh Sultan untuk terus mengingat hal-hal yang dianggap gaib memiliki kekuatan bagi masyarakat adat untuk tetap mempertahankan hubungan ajaran leluhur yang turun-temurun telah diyakini. Hal tersebut mengandung kebenaran karena keyakinan yang terus-menerus diterapkan dalam tiap ritual memberi pengaruh dalam cara berpikir dan penerapan kehidupan masyarakatnya. Jika terdapat kekurangan dalam pelaksanaan tersebut atau melalaikan hal-hal gaib yang telah mereka yakini turun-temurun, akan terjadi musibah atau misfortune. Oleh karena itu, 
pengaplikasian dari mantra ini menjadi simbol pengingat masyarakat adat menjadi salah satu cara menghindari misfortune.

\section{- Mendirikan Tiang Ayu}

Mantra Beluluh menyebut kata "ayunya", jika dihubungkan dalam ritual, kata tersebut mengacu pada tiang ayu yaitu sebuah tombak pusaka bernama Sangkok Piatu. Tombak itu milik Aji Batara Agung Dewa Sakti. Raja pertama pendiri Kesultanan Kutai Kartanegara. Tiang ayu menjadi simbol pegangan hidup masyarakat Kutai dan sekitarnya di bawah Kesultanan Kutai Kartanegara. Pegangan atau pedoman merupakan tata aturan di wilayah Kutai (berhubungan dengan hak ulayat tanah) baik bagi kerabat kesultanan sendiri (masyarakat adat) maupun masyarakat Kutai dan sekitarnya (masyarakat umum yang tinggal di wilayah Kutai) agar dapat sama-sama selalu menjaga dan menaati aturan adat istiadat di wilayah tersebut.

Aplikasi mantra ini terdapat dalam ritual mendirikan tiang ayu yang diletakkan di tengah antara Gong Raden Galuh dan Batu Tijakan. Kedua benda tersebut merupakan pusaka yang mengingatkan pada kisah Putri Karang Melenu (yang masih bayi) saat muncul dari permukaan air Sungai Mahakam. Melalui hitungan ganjil, tiang ayu mulai didirikan yang pertama dalam hitungan satu dua dan tiga pada awal pendirian, tiang ayu yang telah diikat Kain Cinde dan Tali Juwita dipegang oleh tujuh orang atau lebih (hitungan ganjil) mulai diangkat. Selanjutnya, tiang ayu mulai ditegakkan dalam hitungan empat, lima, enam dan tiang ayu berdiri tegak dalam hitungan ketujuh. Dengan berdirinya tiang ayu secara tegak, hal itu menjadi simbol atas pedoman atau tata aturan dasar Kesultanan Kutai telah siap dan dikokohkan kembali.

Hal tersebut memberi dampak psikologis bagi masyarakat adat, selain lebih memperkuat identitas asal usul Kesultanan Kutai, ritual ini memperlihatkan pada masyarakat umum bahwa Kesultanan Kutai masih memiliki pedoman atau tata aturan dalam mengatur wilayah adatnya. Ini dimaksudkan untuk menjaga kelestarian dan keseimbangan hidup serta kedamaian dan kesejahteraan masyarakat di wilayah Kutai yang multietnik.

\section{- Beluluh Sultan saat Erau}

Ritual Beluluh saat Erau dilakukan mulai pembukaan sampai hari terakhir Erau.
Tempat pelaksanaan Beluluh ini dilakukan di halaman Kedaton, disaksikan oleh banyak masyarakat baik dari wilayah Kutai maupun dari luar Kutai bahkan dari luar Pulau Kalimantan. Berbeda dengan Beluluh di dalam Kedaton pra Erau, namun tata cara yang dilakukan sama. Beluluh di halaman Kedaton dilaksanakan untuk dapat membaur dengan masyarakat dari berbagai golongan, suku, dan latar belakang yang beranekaragam. Waktu pelaksanaan pun dilakukan sore hari dan tambak karang yang digunakan setiap hari berbeda-beda mulai awal sampai terakhir. Hal itu diurutkan sesuai dengan maksud Beluluh.

Tambak karang slimpat digunakan di hari pertama pembukaan Erau Penempatan di hari pertama upacara ini bermakna bahwa Erau yang merupakan perayaan besar diadakan untuk kemeriahan seluruh masyarakat umum. Penempatan tambak karang genta di hari kedua Erau di buka merupakan bentuk pengingat hubungan yang terjalin antara manusia dan alam di sekitarnya agar senantiasa dalam kemakmuran dan kedamaian. Tambak karang Indra Geni digunakan pada hari ketiga mengibaratkan seorang pemimpin diharapkan memiliki energi positif yang mampu menghangatkan hati dan membakar semangat rakyatnya mengarah kepada kebaikan, memerangi kejahatan, dan memberikan perlindungan kepada rakyatnya. Tambak karang teratai digunakan pada hari keempat menggambarkan hasrat dan keinginan manusia dalam perjalanan hidupnya tetap dijalani dengan kebaikan sehingga segala sesuatu yang didapatkan akan memberikan suatu kebaikan pula bagi diri dan lingkungan serta alam sekitarnya. Tambak Karang Pauh digunakan pada hari kelima merupakan simbol karakteristik kepemimpinan Sultan Kutai Kartanegara yang memiliki wibawa dan tanggung jawab terhadap rakyatnya. Tambak Karang Daulan digunakan pada hari keenam menyimbolkan keislaman Kesultanan Kutai juga penegas asal muasal keturunan dari Kesultanan Kutai. Terakhir, Karang Nungkul merupakan bentuk harapan dan perwujudan dari Kesultanan Kutai untuk memberikan kebermanfaatan seluruh aktivitas atau kegiatan yang dilakukan pada perayaan Erau bagi semua lapisan masyarakatnya.

Bedasarkan hal itu, Beluluh Sultan di halaman kedaton tidak hanya sekadar ritual semata, namun lebih besar fungsinya secara psikologis memberikan kekuatan bagi masyarakat adat dan Kesultanan Kutai dalam menjalin hubungan dengan masyarakat luas. Masyarakat 
umum dapat merasakan kegembiraan bersama sekaligus mengetahui identitas Kesultanan Kutai secara langsung. Selanjutnya, Beluluh di halaman kedaton tersebut mengantarkan pada ritual-ritual lain yang terkait dengan mantra di dalam Beluluh, yaitu:

\section{- Dewa dan Belian Memuja Ayu}

Pada hari pembukaan Erau, Beluluh sudah mulai dilaksanakan di sore hari menjelang Ashar sebagai penanda dari perayaan Erau. Selanjutnya di malam hari setelah Isya', mulai dapat dilaksanakan kegiatan adat lainnya yang pertama adalah dewa dan belian memuja ayu. Ayu dalam hal ini merupakan simbol dari pokok Kesultanan Kutai seperti yang diperdengarkan oleh belian pada mantranya saat Beluluh di sore hari yang berupa penggalan berikut.

\begin{abstract}
“...dikabarkan ke semua pada pusat kesultanan, pusat yang renggang sudah dieratkan, batang yang condong sudah ditegakkan, tumbuh tunas baru, akar sudah kuat, sudah dikokohkan, sudah diletakkan pada orang yang ditepongtawari,...” (Mt 9)
\end{abstract}

Dalam mantra tersebut disebutkan pokok kesultanan yang renggang sudah dieratkan, yang condong sudah ditegakkan, akan tumbuh tunas, akarnya sudah kuat, sudah dikokohkan, sudah diletakkan pada diri Sultan. Hal tersebut merujuk pada tiang ayu yang sudah didirikan dan sebagai tanda kegiatan lain sudah dapat dilakukan. Selain itu, sebagai simbol kelancaran kegiatan-kegiatan lain, perlu ada pemujaan sebagai wujud rasa syukur kepada Tuhan dengan simbol menyembah ayu (pokok Kesultanan Kutai). Pokok kesultanan sendiri bisa dimaksudkan sebagai prinsip atau pedoman atau pula keyakinan terhadap segala bentuk perilaku kehidupan yang berhubungan dengan Sultan kepada Tuhan, Sultan kepada masyarakatnya, dan Sultan kepada alam sekitarnya sehingga memberikan ketenangan, ketentraman, dan kesejahteraan bersama.

Mengingat Kesultanan Kutai masih memiliki pedoman tersebut di dalam wilayah adatnya, memperbaiki dan menguatkan pedoman dasar itu sangat penting bagi kesejahteraan dan kemakmuran seluruh masyarakatnya. Dengan masih mempertahankan adat budaya leluhur, Kesultanan Kutai membuka pula adat budaya pendatang ataupun modern untuk dapat berkembang di wilayahnya, namun masih melalui aturan dasar yang dimiliki Kesultanan Kutai. Hal tersebut secara psikologis akan menciptakan kekuatan baru bagi kelangsungan adat budaya Kesultanan Kutai yaitu Persatuan dan Kesatuan seluruh masyarakat yang bertempat tinggal di wilayah Kutai dan di sekitarnya.

\section{- Pelas Aji Sultan}

Setelah dewa dan belian memuja ayu, beberapa kegiatan tarian ditampilkan pula seperti Beganjur, Besaong Manok, dan Dewa Memanah. Selanjutnya, kegiatan adat lainnya yaitu Pelas Aji Sultan. Dalam kegiatan ini Sultan melangkah (meniti) di atas tambak karang sambil memegang tali juwita dan kain cinden yang mengikat tiang ayu, bolak balik sebanyak tiga kali yang menyimbolkan kemantapan hati Sultan bahwa tidak ada yang terlewatkan dalam kegiatan yang dilakukan.

Setelah bolak balik sebanyak tiga kali, Sultan baru menginjakkan kaki ke tijakan kaki dekat dengan gong Raden Galuh yang merupakan pusaka saat Putri Karang Melenu muncul dari permukaan air seperti pada kisah kutipan mitologi “... Bayi itu berjenis kelamin perempuan berbaring di atas gong yang dijunjung oleh naga-naga dan Lembu Suana yang berdiri di atas batu. Bayi perempuan tersebut selanjutnya dikenal sebagai Putri Karang Melenu”. Dengan diinjaknya tijakan ini, hal tersebut juga menandai hari atau jumlah hari pelaksanaan Erau yang disusul bunyi ledakan dari meriam buatan di luar kedaton, yang disebut dengan brong.

Penggunaan Kain Cinde selain sebagai simbol pengingat kelahiran Putri Karang Melenu, kain ini diyakini sebagai alat perantara dalam menuju dunia gaib dalam kepercayaan masyarakat adat agar semua kegiatan berjalan dengan baik tidak terjadi bencana. Sementara itu, tali juwita merupakan tali yang lihat dari hitungan akhirnya ditemukan angka 3 (tiga). Jumlah tersebut sama dengan makna dari balai 41. Angka tiga bermakna bahwa setiap apapun di dunia ini pasti mengalami tiga hal yaitu awal, tengah, dan akhir. Dalam Pancasila, angka 3 (tiga) sebagai pemersatu yang berbunyi 'Persatuan Indonesia'. Warna kuning merupakan warna kesultanan, yang khusus digunakan bagi kerabat dan keturunan kesultanan. Melalui simbolisasi ikatan tersebut pula, jika diperumpamakan pada tanaman yang distek. Tanaman itu tidak akan patah oleh hembusan angin dan akan semakin kokoh sampai mendapatkan tunas baru dari 
tanaman tersebut. Hal tersebut dapat dikatakan secara psikologis bahwa ikatan akan menciptakan Persatuan dan Kesatuan pula.

\section{- Mengoyak Rendu dan Mengambil Air Tuli}

Bersamaan acara pelas, kegiatan menggoyang atau menggerak rendu dilakukan. Dewa naik ke atas balai tiang 16 sambil mengoyak randu untuk mengambil Air Tuli. Hal tersebut dilakukan pada saat Pemangku Adat Sakral, belian, beberapa dewa, dan penggawa pembawa air menuju ke Sungai Mahakam.

Mengoyak randu bertujuan mengusir roh-roh jahat atau hal-hal buruk yang mungkin dapat mengganggu kelancaran ritual. Secara psikis, hal tersebut dilakukan berdasarkan keyakinan yang telah turun-temurun ada dalam masyarakat adat dan menjadi suatu kebenaran. Sementara itu, mengambil air tuli dilakukan untuk campuran air tepong tawar maupun air kembang pada saat tepong tawar dilakukan dalam setiap ritual, khususnya Beluluh Sultan.

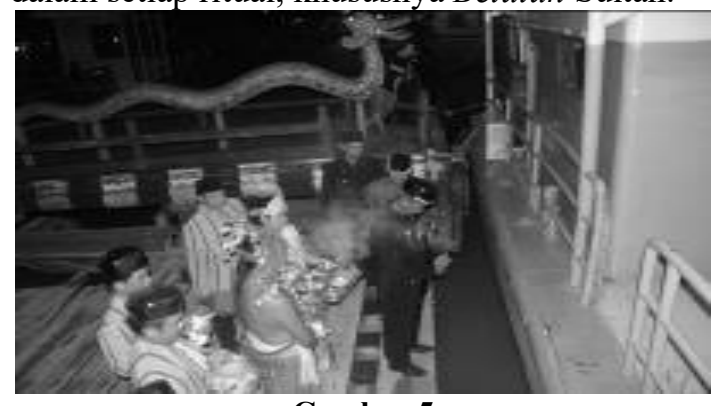

Gambar 5

Mengambil Air Tuli

(Sumber: dokumen Dinas Pariwisata Tenggarong)

Air sebagai sumber kehidupan membawa dampak psikologis bagi manusia. Hal tersebut dikarenakan air yang didapat dengan serangkaian doa kebaikan akan membawa ketenangan dan ketentraman bagi jiwa manusia. Begitupun, air yang diambil melalui ritual mengambil air tuli ini diyakini dapat memberikan kenyamanan pada saat digunakan nantinya karena pengambilannya dilakukan dengan baik.

Selain itu, air juga digunakan untuk membersihkan atau mensucikan diri. Membersihkan atau mensucikan dalam hal ini dapat diartikan membersihkan tubuh dari kotoran yang melekat. Namun, secara psikologis, hal itu dapat diartikan membersihkan atau mensucikan pikiran dan seluruh jiwa manusia yang tidak baik agar nantinya dapat kembali berpikir jernih dan berprasangka baik serta selalu menatap ke depan dengan langkah-langkah yang baik pula.

\section{Fungsi Sosial Perwujudan Kisah Putri Karang Melenu}

Fungsi sosial prosesi adat ini sebagai alat atau sarana komunikasi bagi masyarakat adat dengan masyarakat umum melalui simbolsimbol yang digunakan. Dengan berbagai simbol yang melengkapi prosesi adat ini, masyarakat adat merasakan kedekatan antara satu dengan yang lainnya untuk terus dapat menjaga identitasnya. Komunikasi masyarakat adat dengan dinas pemerintahan terjalin karena terkait dengan kelangsungan kebudayaan Kutai, komunikasi masyarakat adat dengan masyarakat umum lainnya dalam menjaga kesatuan dan perdamaian di wilayah Kutai, serta masyarakat adat dengan alam sekitarnya yang senangtiasa saling membutuhkan. Berdasarkan hal tersebut, fungsi sosial perwujudan Kisah Putri Karang Melenu dalam Adat Beluluh Sultan dibagi menjadi tiga (Janah, 2016), yaitu:

\section{- Memperkuat Kedudukan Sultan di Lingkungan Kesultanan Kutai}

Beluluh Sultan merupakan ritual yang memiliki fungsi dan makna sangat kompleks serta utuh. Di dalam ritual ini terdapat sejumlah rangkaian persiapan adat mulai dari tambak karang, perlengkapan ritual terutama balai 41 , dan pelaksanaan Beluluh sendiri beserta mantra yang mengiringinya. Beluluh Sultan merupakan penguat posisi sultan sebagai pemimpin adat di wilayah Kesultanan Kutai Kartanegara. Pertama melalui ukiran tambak karang yang mengisahkan naga sebagai totem Putri Karang Melenu. Naga sendiri di masyarakat Kutai menyimbolkan kekuatan yang dapat memberikan kebaikan dan keberuntungan bagi umat manusia. Simbol naga dianggap religius pada dasarnya berfungsi menjembatani antara dunia manusiawi dan Ilahi. Ilahi dalam hal ini secara mitologi menggambarkan sosok dewa ataupun manusia yang dianggap keturunan dewa sebagai penguasa, dalam hal ini berkaitan dengan sosok Putri Karang Melenu yang kelahirannya dianggap gaib dan ia digambarkan sebagai titisan dewa, yang untuk zaman sekarang diwujudkan sosok penguasa kesultanan yaitu Sultan Kutai Kartanegara.

Kedua, balai 41 merupakan penggambaran singgasana Putri Karang Melenu berada di 
mahligai, tempat pertama kalinya ia meninjakkan kaki ke tanah. Balai 41 dibuat dari bambu kuning. Warna kuning merupakan warna kesultanan. Warna ini memiliki makna kemakmuran dan kesejahteraan. Oleh karena itu, balai 41 selain menyimbolkan suatu poros terciptanya persatuan seluruh masyarakat di wilayah Kutai Kartanegara, sebagai simbol bahwa Sultan yang merupakan penguasa Kesultanan Kutai juga sebagai sosok yang diharapkan dapat membawa Kutai pada kemakmuran dan kesejahteraan bagi rakyat dan wilayahnya. Selain itu, tijakan kaki yang terdapat di bagian depan balai 41 memperkuat kedudukan sultan karena menyimbolkan strata sosial atau kedudukan Sultan sebagai Raja atau pemimpin di Kesultanan Kutai Kartanegara yang dikhususkan hanya untuk Sultan. Hal tersebut juga penggambaran dari kisah Putri Karang Melenu bagaimana ketika akan meninjakkan kakinya ke tanah pertama kalinya.

Ketiga, kirap tuhing dalam pelaksanaan Beluluh dengan menggunakan kain kuning sebagai payung sultan pada saat Prosesi Beluluh Sultan merupakan penggambaran Putri Karang Melenu yang masih bayi dipayungi mega digantikan dengan kain kuning yang melambangkan kedudukan Putri Karang Melenu sebagai bangsawan kesultanan begitupun Sultan Kutai Kartanegara saat ini. Selanjutnya, pemercikan air tepong tawar pada sultan dalam Prosesi Beluluh Sultan sebagai tanda pensucian diri merupakan representasi Putri Karang Melenu yang terlahir sebagai bayi yang suci. Begitu kuatnya penggambaran Putri Karang Melenu dalam pelaksanaan Beluluh Sultan, hal itu menjadi penguat identitas sekaligus kedudukan sultan di Kesultanan Kutai Kartanegara sebagai sosok pemimpin dari keturunan yang memiliki keistimewaan karena bukan dari orang biasa.

Keempat, penguat kedudukan Sultan terdapat pula pada mantra Beluluh, salah satunya pada rangkaian kata terakhir dari Mt 3.6 "minta babari lontar babari surat" artinya memberitahukan pengetahuan orang yang mau naik tahta diikat ke pusatnya. Rangkaian kata "babari lontar" dan "babari surat" sendiri memiliki pengertian yang sama yaitu suratan takdir diberitahukan. Pemberitahuan ini ditujukan kepada Sultan, orang yang akan diluluh dan itu pun merujuk pada Mt 3.4 "urang bukammit urang bukallam ting budi kancaseran" yang artinya orang yang mau naik ke singgasana supaya berkarisma. Berdasarkan mantra tersebut, kedudukan sultan sebagai pimpinan merupakan garis hidup yang dijalani sehingga singgasana sebagai simbol status sultan memperkuatnya dan sebagai pemimpin di Kesultanan Kutai, sultan digambarkan sebagai sosok karismatik yang berbeda dengan lainnya.

\section{- Menjaga Kelestarian Budaya Kutai Bersama-sama Dinas Pemerintah}

Masyarakat adat dalam menjaga kelestarian budayanya, salah satunya Beluluh Sultan tidak dapat hanya mengandalkan kelompok di lingkungan Kesultanan Kutai semata. Kerja sama dengan Dinas Pemerintah terkait diperlukan demi keberlangsungan budaya Kutai. Dinas Pemerintah Pariwisata dan Budaya Tenggarong ikut serta dalam mengabadikan setiap momen ritual adat ataupun kegiatan adat lainnya mulai Beluluh Sultan pra-Erau sampai berakhirnya perayaan Erau.

Hal tersebut sangat membantu masyarakat adat ketika banyak masyarakat terutama di dunia akademik mulai tertarik dengan kebudayaan Kutai, mereka akan dapat menemukan banyak informasi baik secara langsung maupun melalui website yang dimiliki dinas terkait misalnya, www.visitingkutaikartanegara. com dan www.kutaikartanegara.com milik Dinas Kebudayaan dan Pariwisata Tenggarong yang banyak membantu mempromosikan tidak hanya tempat wisata dan hal-hal lain terkait dengan Kabupaten Kutai Kartanegara, tetapi ikut serta dalam mempromosikan kebudayaan Kutai seperti perayaan Erau yang di dalamnya terdapat ritual Beluluh Sultan. Tidak hanya sekedar promosi waktu, tempat, atau kegiatan apa saja selama perayaan adat, mereka pun memberikan banyak penjelasan secara garis besar seluruh rangkaian adat dari awal sampai akhir sehingga dapat menarik minat masyarakat umum baik domestik maupun mancanegara.

Pemerintah Kabupaten Kutai Kartanegara melalui Dinas Kebudayaan dan Pariwisata banyak memberikan bantuan dalam pelestarian kebudayaan Kesultanan Kutai Kartanegara tiap tahunnya. Kerja sama yang terjalin antara masyarakat adat dan pemerintah melalui dinas terkait memberikan keuntungan kedua belah pihak, satu sisi Kesultanan Kutai masih dapat menjaga identitasnya dan melestarikan kebudayaan yang dimiliki dan pemerintah dapat memberikan peluang besar bagi kemajuan wilayahnya terutama dari segi perekonomian masyarakatnya karena tingkat pariwisata semakin maju. Hal 
tersebut dapat dilihat dengan digelarnya International Folk \& Art Festival (EIFAF) 2015 ini dan sekaligus festival daerah.

Pada festival ini seni budaya daerah dari beberapa suku di Indonesia ikut ditampilkan sebagai bentuk keterbukaan masyarakat adat terhadap kebudayaan di Indonesia. Peserta mancanegara pun tidak ketinggalan memperkenalkan kebudayaan mereka. Hal tersebut memberikan peluang besar kerja sama pemerintah daerah dengan daerah lain sekaligus dengan negara lain untuk saling mempromosikan kebudayaan masing-masing. Dengan demikian, kebudayaan Kutai dapat dikenal oleh daerah dan negara lain sebagai suatu budaya yang sangat menjaga kebersamaan dan keterbukaan terhadap budaya luar selama masih dalam alur pedoman Kesultanan Kutai Kartanegara dalam menjaga kelestarian kebudayaannya.

\section{- Menjalin Persatuan dan Perdamaian demi Kesejahteraan Bersama Masyarakat di Wilayah Kutai}

Prosesi ini membawa seluruh masyarakat berkumpul dalam kemeriahan, membaur menjadi satu tanpa memandang asal-usul, pangkat, maupun golongan. Sebagai contoh, hal itu dapat dilihat saat banyak masyarakat berkumpul menunggu prosesi Beluluh (Janah, 2016).

Prosesi Beluluh ini dalam tambak karang slimpat yang digunakan di hari pertama pembukaan Erau merupakan simbol bahwa perayaan besar ini diadakan untuk kemeriahan seluruh masyarakat umum. Dalam hal ini, Kesultanan Kutai sebagai masyarakat adat memberikan penghargaan bagi segenap masyarakatnya di awal pembukaan untuk ikut serta dalam perayaan tersebut. Itu merupakan salah satu bentuk komunikasi yang terjalin antara masyarakat adat dengan masyarakat umum yang diaplikasikan dalam ukiran tambak karang.

Ritual ini pun berfungsi mempersatukan seluruh masyarakat yang ada di wilayah Kesultanan Kutai Kartanegara tanpa melihat dari suku mana mereka berasal. Banyaknya masyarakat tidak hanya dari masyarakat Kutai saja namun dari berbagai daerah di Indonesia yang bertempat tinggal di sekitar wilayah tersebut sangat antusias dalam mengikuti gelaran ritual ini, bahkan ada yang benar-benar datang dari luar Kalimantan baik itu undangan dari Kesultanan Kutai secara langsung ataupun mereka datang secara pribadi turut menyaksikan. Ritual ini tidak hanya menunjukkan jati diri masyarakat Kutai dan Kesultanan Kutai semata, namun lebih besar lagi ritual ini menunjukkan bagaimana Kebhinekatunggalikaan ditampakkan.

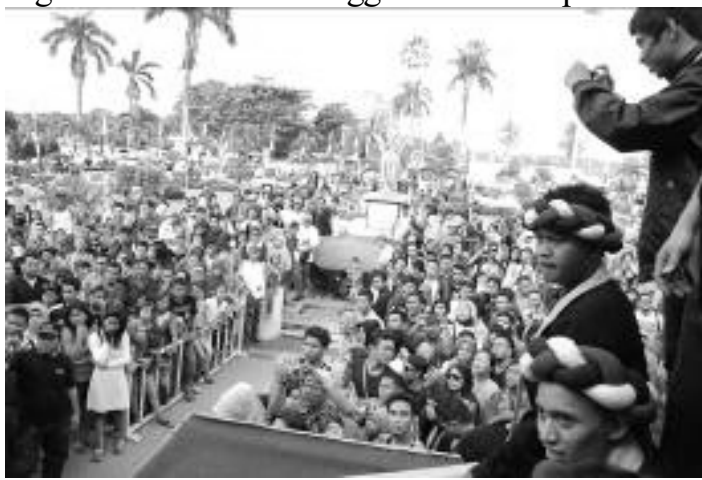

Gambar 6

Antusias masyarakat mengikuti Prosesi Adat Beluluh Sultan

(Sumber: Dokumen Dinas Pariwisata Tenggarong)

Hal itu dapat dilihat dari pemaknaan balai 41 jika diperhatikan angka 41 disumkan, didapati angka 3. Dalam Pancasila, angka 3 sebagai pemersatu yang berbunyi 'Persatuan Indonesia'. Dengan kata lain, balai 41 meyimbolkan suatu poros terciptanya persatuan seluruh masyarakat di wilayah Kutai Kartanegara dalam suatu perayaan adat.

Kekuatan pemersatu menjadi akar yang kuat bagi Kesultanan Kutai Kartanegara sebagai masyarakat adat dalam memimpin wilayahnya yang memiliki beraneka ragam suku dan budaya baik dari suku asli maupun suku pendatang. Mantra Beluluh yang menunjukkan kekuatan pemersatu yaitu "jadi tua tugan akar ipuh tugan batang" artinya ke semua orang berdiri kokoh ibarat akar tunggal. Sementara itu, keberanekaragaman suku dan budaya asli serta pendatang yang menyatu menjadi kekayaan terbesar di wilayah adat Kutai ditunjukkan pada kata "sugara loka lautan lambur". Secara kebahasaan, sugara sama dengan lautan ataupun samudra.

Selain menjalin persatuan ditunjukkan antara masyarakat adat dengan masyarakat umum, pada salah satu mantra Beluluh Mt 3.1 dijelaskan tentang kata "pedalaman" bertempat tinggalnya masyarakat pedalaman yang masih banyak di antaranya meyakini kepercayaan lamanya, kaharingan, mempercayai banyak dewa, seperti dewa penguasa tanah, sungai, pohon, batu, dan sebagainya. Bagian kedua terdapat kata "barhala" dan "dewa" yang merujuk pada kepercayaan masyarakat pedalaman, dianggap 
suatu keyakinan turun-temurun yang tidak dapat diabaikan. Konsep keyakinan ini mengandung nilai keseimbagan atau keharmonisan antara sesama manusia, manusia dengan alam dan manusia dengan Tuhan yang sampai saat ini diaplikasikan oleh masyarakat pedalaman dalam melindungi alam sekitar tempat tinggal mereka. Masyarakat adat (Kutai) pun turut meyakini nilai tersebut sebagai wujud keseimbangan menjaga hubungan mereka dengan alam sekitar dan juga dengan sang pencipta untuk kesejahteraan seluruh masyarakat di wilayah Kutai.

Sementara itu dalam prosesi Beluluh, hubungan tersebut tergambar pada ukiran Tambak Karang Genta. Tambak karang ini memiliki simbol lonceng sebagai bentuk pengingat hubungan manusia dengan alam sekitarnya agar senantiasa dalam kemakmuran dan kedamaian. Hal tersebut diharapkan pula dapat menghindarkan diri dari misfortune.

\section{Penutup}

Perwujudan sebuah karya sastra yang berdasarkan kisah mitos ke dalam bentuk karya seni rupa dan prosesi adat merupakan bentuk simbolik yang bermakna bagi masyarakat pemilik adat. Tiap masyarakat, terutama masyarakat pemilik adat membutuhkan aturan-aturan yang diciptakan untuk dijadikan landasan kebenaran dalam menata wilayah adatnya. Hal tersebut dilakukan sebagai wujud keseimbangan antara manusia dengan penciptanya, manusia dengan alam dan manusia dengan masyarakat sekitarnya. Melalui acara kebudayaan, misalnya upacara adat yang merujuk pada cerita rakyat setempat berupa ritual Beluluh, pemilik adat di Tenggarong mencoba meneguhkan identitasnya sekaligus memperkenalkannya pada masyarakat umum. Pendatang sendiri dapat mengetahui, menghargai,dan ikut berpartisipasi dalam kelangsungan budaya lokal.Hal itu bertujuan agar kebudayaan lokal tidak punah dan pendatang dapat hidup berdampingan dengan masyarakat setempat dengan pengetahuan simbol-simbol seperti seni rupa dalam tambak karang yang digunakan sebagai alas balai 41 pada saat Beluluh.Tambak karang mengisahkan tentang naga sebagai totem dari Putri Karang Melenu sebelum muncul dengan wujud manusia.Prosesi adat Beluluh Sultan merupakan hasil perwujudan karya sastra kisah Putri Karang Melenu ketika muncul di atas gong Raden Galuh dari permukaan air yang dijunjung oleh naga-naga dan Lembu Suana yang berdiri di atas batu. Pembuatan tambak karang secara ekspresif merupakan bentuk dari implikasi imitasi imajinatif masyarakat adat terhadap kisah Putri Karang Melenu. Pembuatan tambak karang tersebut juga masih memikirkan nilai estetik dan beberapa logika alam serta keseharian manusia.

Masyarakat adat dengan masih melestarikan tradisi Beluluh ini secara kreatif menunjukkan bahwa pemerintah Kesultanan Kutai masih ada dan masih berdiri kokoh dengan silsilah serta adat yang terus dipegang dari keturunan sebelumnya. Hal tersebut diperlihatkan dengan masih terjaganya ritual sakral Prosesi Beluluh Sultan pada setiap upacara adat Erau tiap tahunnya sebagai simbol khusus bagi pimpinan Kesultanan Kutai yang berkuasa yang menggambarkan keturunan kuat dari Putri Karang Melenu, ibu dari sultan-sultan Kutai Kartanegara Ing Martadipura.

Masyarakat adat secara psikologi diharapkan mendapatkan ketenangan, keberkahan, kesejahteraan, dan terhindar dari segala musibah dengan diselenggarakan prosesi adat tersebut. Sementara itu, secara sosial dengan berbagai simbol yang melengkapi prosesi adat ini, masyarakat adat merasakan kedekatan antara satu dengan yang lainnya. Prosesi ini membawa seluruh masyarakat berkumpul dalam kemeriahan, membaur menjadi satu tanpa memandang asalusul, pangkat, maupun golongan. Hal tersebut menampakkan simbol Persatuan dan Kesatuan di wilayah Kutai dan sekitarnya serta memiliki timbal balik positif terhadap pembangunan Indonesia di masa mendatang.

Sementara itu, pemerintah daerah Kabupaten Tenggarong pun dapat ikut serta bersama masyarakat adat melestarikan kebudayaan. Pemerintah daerah dapat memajukan daerahnya melalui peningkatan pariwisata daerahnya baik pada wisatawan domestik maupun internasional misalnya, menyelenggarakan kegiatan-kegiatan budaya pada saat perayaan adat seperti International Folk \& Art Festival (EIFAF) dan sekaligus festival daerah. Hal tersebut dapat memberikan dampak pada pariwisata Tenggarong di tahun-tahun berikutnya.

\section{Daftar Pustaka}

Badcock, C.R. (2008). Levi-Strauss Strukturalisme dan Teori Sosiologi. Yogyakarta: Pustaka Pelajar. 
Eliade, M. (2002). Mitos:Gerak Kembali yang Abadi. Yogyakarta: Ikon Teralitera.

Freud, S. (2001). Totem and Taboo. London: Routledge.

Ismail. (1990). Burong. Jakarta: Erlangga.

Janah, U. (2016). Beluluh Sultan;Ritual Sakral Pada Pelaksanaan Erau. Yogyakarta: Sibuku Media.

Kutai, P.D. (2003). Dari Swapraja ke Kabupaten Kutai. Tenggarong, Kalimantan Timur: Pemerintah Daerah Kabupaten Kutai.
Peirce, C.S. (1931). Collected Papers of Charles Sanders Peirce. C. Hartshorne, \& P. Weiss, (Penyunting). Cambridge, Massachusetts: Harvard University Press.

Ratna, N.K. (2011). Antropologi Sastra: Peranan Unsur-Unsur Kebudayaan dalam Proses Kreatif. Yogyakarta: Pustaka Pelajar.

Sayekti, S. (2010). Silsilah Kutai Kartanegara Eyang Martadipura. Jakarta: Pusat Bahasa Kemendikbud. 